Pamiętnik Literacki 2019, 1, s. 212-225

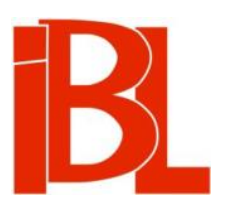

\title{
Korespondencja Zygmunta Haupta z Jerzym Stempowskim
}

Oprac. Aleksander Madyda 
Pamiętnik Literacki CX, 2019, z. 1, PL ISSN 0031-0514

DOI: $10.18318 / \mathrm{pl} .2019 .1 .12$

\title{
KORESPONDENCJA ZYGMUNTA HAUPTA Z JERZYM STEMPOWSKIM
}

\author{
Opracował \\ ALEKSANDER MADYDA Uniwersytet Mikołaja Kopernika, Toruń
}

O istnieniu tych listów wiadomo było już od pierwszej połowy lat siedemdziesiątych ubiegłego stulecia, kiedy to Zygmunt Haupt, publikując w paryskiej „Kulturze” (1972, nr 4) opowiadanie $Z$ Laczczyny, opatrzył je swoistym komentarzem w postaci listu Jerzego Stempowskiego z 11 I 1966 (nr 9 w przyjętej tu numeracji), w którym znalazło się m.in. sformułowanie wykorzystane przez pisarza do zatytułowania utworu. W liście do Jerzego Giedroycia z 16 II 1972 tak się z tego tłumaczył przed redaktorem:

Cieszę się, że to, co posłałem Panu, nadaje się do „Kultury”. Materiał ten jest rodzajem hommage ${ }^{1}$ spłaconym nieodżałowanej pamięci Stempowskiemu ${ }^{2}$. Już nie staje po tej czy tamtej stronie umysłu tak przenikliwego, o takiej wiedzy i rozumieniu stosunków ludzkich, sztuki, świata [jak umysł] autora Esejów dla Kassandry ${ }^{3}$. Może coś jeszcze ocalało po nim, Pan pewnie wie. Chociażby listy, z których każdy jest znakomitym esejem, jakiego przykład pozwoliłem sobie załączyć do mego ostatniego listu do Pana. Stempowski bardzo konsekwentnie potrafił przez kilka takich listów podtrzymywać jeden temat, mam na przykład prawdziwe jego krótkie studium o pisarskim dziwolagu, jakim był Ritter von Sacher-Masoch. Sa pewni ludzie, których darzył osobista przyjaźnią i którzy pewnie zachowali to, co do nich pisał i dużo. Ja zasłużyłem sobie na jego przychylność bardzo późno, za późno. Zapytuje Pan, czy nie mam zastrzeżeń co do zamieszczenia wzmiankowanego listu Stempowskiego do mnie wraz z mym opowiadaniem. Jego pierwsza część jest czarującą relacją z myślowych wędrówek „z Laczczyny na Tureczczynę"4 . Natomiast w części drugiej autor listu jest bardzo na [!] mnie łaskaw za moje własne pisanie i mam z tego powodu słuszny powód do dumy. Pan może wybaczył mi, że listem tym popisałem się przed Panem samym, ale boję się tego popisu przed czytelnikami. A pokusa jest wielka, bo to, co robię w osamotnieniu i co Pan łaskawie aprobuje do druku, domaga się takiej czy innej krytyki, a ta jest głucha; chyba z całym zaufaniem zdam się na własny sąd Pana ${ }^{5}$.

Po raz drugi i zarazem ostatni posłużył się pisarz dwoma innymi listami Stempowskiego - tu: nry 4 i 7 - włączając skompilowane w jeden fragment obszerne $z$ nich cytaty do eseju Inwokacja do powiatu latyczowskiego („Kultura” 1973, nr 7/8). Wszystkie te trzy listy przetrwały w archiwum Haupta, znajdującym się w Green Library na Uniwersytecie Stanforda ${ }^{6}$, lecz co się stało z jego listami do autora Od Berdyczowa do Rzymu, nie było wiadomo aż do r. 2016, kiedy to udało mi się całkowicie przypadkowo odkryć kompletną korespondencję - siedem listów - Haupta do Stempowskiego w miejscu, w którym szukałem zupełnie

hommage (fr.) - hołd.

Jerzy Stempowski zmarł 4 X 1969 w Bernie.

Pierwodruk Esejów dla Kassandry J. Ste m p ow s ki e go ukazał się w Paryżu w 1961 r. w Instytucie Literackim.

4 Zob. list 9, przypis 11.

5 J. Gi i droy c, Z. H a u pt, Listy 1949-1975. Archiwum Instytutu Literackiego w Paryżu.

6 Zygmunt Haupt papers, 1939-1976. Department of Special Collections and University Archives Stanford University Libraries. Collection number M0356, box 2, folder 8 . 
czegoś innego: w zasobach archiwalnych Instytutu Pamięci Narodowej ${ }^{7}$. Miałem bowiem nadzieję, że autor Pierścienia z papieru, korespondujący $\mathrm{z}$ wieloma bliskimi i znajomymi zamieszkującymi Polskę ${ }^{8}$, będzie monitorowany przez Służbę Bezpieczeństwa na tyle uważnie, że w jej kartotekach pozostaną przynajmniej odpisy jego listów. Tymczasem, jak się okazuje, SB przejęła korespondencję krążąca między USA a Szwajcarią - jakim cudem, tego nikt w IPN-ie nie potrafił mi wyjaśnić.

Genezę tej korespondencji, prowadzonej od kwietnia 1963 do stycznia 1966, stanowi fakt przyznania Hauptowi Nagrody Literackiej „Kultury” za utwory publikowane na łamach tego paryskiego miesięcznika oraz londyńskich „Wiadomości”, a także - w wersji angielskiej $\mathrm{w}$ amerykańskich periodykach literacko-artystycznych ${ }^{9}$. Pisarz, jak zaświadcza list nr 1 , poczuł się zobowiązany do wyrażenia wdzięczności Stempowskiemu, który zasiadał w jury, za jego słowa uznania wydrukowane w zamieszczonym w „Kulturze” (1963, nr 1/2) uzasadnieniu przyznania nagrody. Juror natychmiast odpisał, ale list datowany 30 IV 1963 zaginał, niemniej na podstawie kolejnego listu Haupta, nr 3, w którym autor przyznaje się do „nieporządku pisarskiego" ${ }^{10}$, do niechlujności w maszynopisie zbioru opowiadań przesłanym do Maisons-Laffitte ${ }^{11}$, możemy się domyślać, że ów zaginiony list był bardzo podobny pod względem treści do tego z 30 X 1962, adresowanego do szefa Instytutu Literackiego, a zawierającego świeże wrażenia Stempowskiego z lektury debiutu książkowego jego późniejszego korespondenta:

$Z$ tym rękopisem ${ }^{12}$ będzie Pan miał jeszcze trochę zmartwienia, bo nie jest przygotowany do druku. Autor nie okazuje żadnego starania o poprawność swego tekstu. Nie trzyma się więc żadnej pisowni; w jego rękopisie znaleźć można elementy wszystkich ortografii praktykowanych w Polsce w ciągu ostatnich 50 lat. To samo dotyczy przestankowania, które trzeba by ustalić w całym tekście, bo nie ma w nim ani jednej stronicy mającej jakiś konsekwentny system znaków przestankowych. Na opiekę zasługują też wyrazy francuskie, rozsiane dość hojnie w rękopisie. Poprawiłem je z gruba. Nie ma bodaj ani jednego, który by nie miał jakiegoś defektu ortograficznego. Najlepiej byłoby może dać je wszystkie kursywą, co ułatwi potem ich korektę. Najtrudniejszą jednak rzeczą będzie poprawienie zdań, w których niepoprawna jest składnia. Uwzględniając nawet największą swobodę $\mathrm{w}$ tej dziedzinie, trzeba będzie wiele zdań wyprostować, aby nie robiły wrażenia niechlujnego, niepoprawnego mimo woli, jak „drzewa wysadzające drogę" 13 .

Jeżeli chodzi o meritum literackie rękopisu, nie można mu odmówić wartości, jakkolwiek też od tej strony nie jest gotowy do druku. Zyskałby moim zdaniem wiele, gdyby dokonać w nim pewnego wyboru, odrzucając parę rozdziałów słabszych, jak Madrygał dla Anusi i Dziewczynka z nóżkami na księżycach, a być może też dwa inne. Właściwie każdy autor powinien mieć jakiegoś przyjaciela, który by robił w jego utworach użyteczne skróty. Przydałoby się to nawet samemu Goethemu. $Z$ rękopisu Haupta widać, że brak mu takiego przyjaciela.

7 Sygnatura archiwalna: IPN BU 2889/164.

8 Zob. Z. H a u pt, list do Z. Ruszkowskiego, z 1 VII 1948. W: Zdzisław Ruszkowski papers, 1925-1972. Department of Special Collections and University Archives Stanford University Libraries. Collection number MISC0239, folder 1-3: „koresponduję z rodziną w Polsce i z kilkorgiem przyjaciół tam”. Haupt w czasie drugiej wojny światowej opuścił Polskę 19 IX 1939, potem poprzez Węgry i Francję przedostał się do Wielkiej Brytanii, skąd w 1946 r. wyjechał na stałe do Stanów Zjednoczonych, dwa razy tylko odwiedzając Europę.

9 Zob. J. Gie dro y c, list do J. Stempowskiego, z 6 X 1962. W: J. Gi e d r oy c, J. St e m p ow ski, Listy 1946-1969. Wybór, wstęp, przypisy A. S. Kow al czy k. Cz. 2. Warszawa 1998, s. 208.

10 Zob. list 3.

11 Zbiór ten, zatytułowany Pierścień z papieru, został wydany w Paryżu w 1963 r. przez Instytut Literacki.

12 Stempowski konsekwentnie nazywa maszynopis Pierścienia z papieru rękopisem.

13 Stempowski przytacza tu cytat z omawianego maszynopisu. W wersji drukowanej Pierścienia z papieru sformułowania tego nie ma. 
[...] Szkice Haupta nie są tworami wyobraźni. Autor widział to, o czym pisze, wykazując niezwykłą spostrzegawczość i talent do oddawania rzeczy widzianych. Opisuje też ludzi żywych, niektórych zapewne pod ich własnymi nazwiskami, jak w szkicu Biały mazur. Sa to raczej wspomnienia, szkice memorialisty. [...] Jest on świetnym memorialistą. Jego Galicja Wschodnia jest come viva. Jako twory wyobraźni, natury literackiej, szkice jego byłyby mniej przekonywające. Jest zresztą pewna różnica między jego obrazami z Galicji i z Francji. Ewokacja dawnej Galicji Wschodniej daje prawdziwe złudzenie rzeczywistości; autor posiada do tego celu język przylegający ściśle do rzeczy i ludzi. W obrazach Francji musi więcej polegać na wyobraźni, i to mu się mniej udaje.

$[\ldots]$

Szkice Haupta wyróżniają się same przez swą odmienność od tego, co się dziś pisze, przez swą odległość od modnych manieryzmów. Posiadają samobytność zasługującą na uwagę. W ocenie ich przeszkadza trochę niezdecydowanie ich rodzaju literackiego. Świetne jako szkice pamiętnikarza, są wątpliwe jako nowele, nie spełniając wymagań tego rodzaju literackiego. [...]

Uwaga: stronice rękopisu nie są ponumerowane i w jednym miejscu miałem wrażenie luki ${ }^{14}$. Gdyby się rozsypał, byłoby na tydzień roboty" 15 .

Zarysowujące się w listach spore różnice między pisarzami co do gustów artystycznych i stylistycznych, nie mówiąc już o niezaprzeczalnej dysproporcji w dziedzinie erudycji i wykształcenia oraz o odmienności zainteresowań lekturowych i onieśmielającym Haupta respekcie dla pozycji literackiej Stempowskiego, sprawiły, że ich korespondencja trwała krótko i była niezbyt obfita, dlatego w oczach dzisiejszego czytelnika staje się ona bardziej przyczynkiem do poznania biografii i osobowości artystycznej autora Pierścienia z papieru niż istotnym źródłem wiedzy o eseiście $z$ Berna.

Pisownię i interpunkcję listów zmodernizowano według aktualnie obowiązujących zasad, zachowując sporadycznie występujące osobliwości leksykalne, charakterystyczne dla pisarskiego idiolektu, oraz stosowaną niekiedy przez Haupta majuskułę. Ujednolicono też układ nagłówków, adresów i podpisów. Nieliczne niezbędne uzupełnienia redakcyjne podano w nawiasach kwadratowych.

\section{Zygmunt Haupt do Jerzego Stempowskiego}

\section{1, OAKCREST ROAD} ARLINGTON, VA.

\section{9/IV/[19]63}

\section{Szanowny Panie!}

Chcę Panu bardzo podziękować za to, co zechciał Pan napisać w numerze za styczeń-luty „Kultury” o moich wysiłkach ${ }^{1}$. Powinienem był to zrobić wcześniej, ale nie znałem adresu Pana. Adres ten podał mi Jerzy Giedroyc dopiero niedawno. Powinienem był poprosić o to za mej bytności w styczniu w Maisons-Laffitte, ale po prostu przegapiłem tę okazję.

Pana uwagi o mym pisaniu bardzo sobie cenię, tym bardziej że mam tyle re-

Luka ta występuje w opowiadaniu Z. Ha u p t a Meine liebe Mutter, sei stolz, Ich trage die Fahne (w: Pierścień z papieru. Maszynopis Archiwum Instytutu Literackiego w Paryżu) - między s. 4 a 5 maszynopisu: „Z Januarym przede wszystkim rano wychodziliśmy [koniec s. 4! - A. M.] W tym Szymbarku-Bystrzycy byłem tylko trzy razy albo dwa - tyle lat temu, że nawet nie pomnę, ile to razy było”. W wersji drukowanej fraza „Z Januarym przede wszystkim rano wychodziliśmy” została po prostu opuszczona. 
spektu dla tego, co Pan sam pisze. O samym Panu słyszałem także w styczniu w Paryżu od mego lwowskiego przyjaciela Andrzeja Kruczkowskiego ${ }^{2}$, który niedawno widział Pana w Bernie. Znał on kiedyś także, jak mi mówił, Pana Stanisława Stempowskiego ${ }^{3}$. Kruczkowski ma straszny kłopot ze wzrokiem i bardzo mi go żal. Ale potrafił zapomnieć o tym, kiedy mogliśmy sobie porozmawiać o dawnych czasach.

Dla mnie po 15 latach w Ameryce pierwsza wizyta w Europie (tej, co ma na głowie „coronę turritę"4) była nostalgicznym przeżyciem. Następnym razem wybiorę się chyba tam po krótszym przedziale czasu ${ }^{5}$.

Kończąc te słowa, jeszcze raz dziękuję i przesyłam wiele pozdrowień

\section{Zygmunt Haupt}

List pisany odręcznie, piórem, niebieskim atramentem, na dwóch czystych kartach papieru formatu A4.

1 P. H. [P. H o s tow i e c, pseud. J. S t e m p ow s ki e g o], Nagroda Literacka „Kultury” za rok 1962 - Zygmunt Haupt. „Kultura” 1963, nr 1/2.

2 Andrzej Zdzisław Kr u c z k o w s k i (1912-2006), redaktor i publicysta, po wojnie współpracownik „Rzeczypospolitej” Jerzego Borejszy, później urzędnik Ministerstwa Spraw Zagranicznych i Ministerstwa Handlu Zagranicznego. W Polsce międzywojennej współpracownik lwowskich czasopism „Małopolanin. Wczoraj - dziś - jutro” i „Sygnały” oraz współzałożyciel „Lwowa Literackiego”.

3 Chodzi o ojca Jerzego Stempowskiego.

4 Aluzja do: P. Ho s tow i e c [J. St e m p ow s ki], Corona turrita. (Z dziennika podróży do Włoch). „Kultura” 1948, nry 5-6.

$5 \quad$ Kolejną i zarazem ostatnią podróż do Europy odbył Haupt w 1971 roku.

\section{Zygmunt Haupt do Jerzego Stempowskiego}

1021, OAKCREST ROAD ARLINGTON, VA.

$27 / \mathrm{V} /[19] 63$

\section{Szanowny i Kochany Panie!}

Proszę mi wybaczyć, że w tej chwili piszę tylko parę słów w odpowiedzi na list Pana z 30/IV ${ }^{1}$. Był on wysłany pocztą lotniczą, ale widocznie przez pomyłkę szedł dłuższą drogą, bo dostałem go dopiero teraz. Chcę przede wszystkim potwierdzić jego odbiór i podziękować Panu za tyle uwagi i przychylności, jakie Pan zechciał okazać mej pracy. Bardzo jestem Panu wdzięczny, a także zaszczycony. W ślad za tym listem wyszlę drugi, obszerniejszy, ale chciałbym się nad nim namyślić ${ }^{2}$.

Jeszcze raz dziękuję i łączę słowa poważania i pozdrowienia

\section{Zygmunt Haupt}

List pisany odręcznie, piórem, niebieskim atramentem, na karcie papieru formatu A4.

1 List Stempowskiego nie zachował się.

2 Zob. list 3. 


\section{Zygmunt Haupt do Jerzego Stempowskiego}

1021, Oakcrest Road Arlington, Virginia

18/VIII/[19]63

\section{Szanowny i Kochany Panie!}

Przede wszystkim chciałbym Panu serdecznie pogratulować nagrody im. Godlewskiej $^{1}$.

Proszę mi wybaczyć, że tak późno odpowiadam obszerniej na list Pański z 30 kwietnia. Doszedł mnie późno i wtedy tylko potwierdziłem jego odbiór. Byłem bardzo zaszczycony i ujęty uwagą, jaką chciał Pan przywiązać do mego pisania, i jestem niezmiernie wdzięczny za komentarze i rady zawarte w liście Pana. Godzę się $\mathrm{z}$ rozmaitymi zastrzeżeniami Pana tyczącymi się zwłaszcza nieporządku pisarskiego i powinienem $z$ wielu rzeczy wytłumaczyć się przed Panem. Manuskrypt książki przedstawiony Giedroyciowi ${ }^{2}$ był niechlujny, a to dlatego, że do ostatniej chwili nie byłem pewien, czy „KULTURA” zechce ją wydać, a kiedy do tego cudu doszło, to od razu bardzo mnie piłowano, ażeby manuskrypt wysłać. Myślałem, że w czasie bytności w Paryżu będę mógł posiedzieć nad korektą, ale miałem tylko parę dni czasu i odbitki szczotkowe napływały bardzo powolnie $z$ drukarni. Poza tym nie mam cnoty cierpliwości, a także bałem się, ażeby nie dać się ponieść manii poprawiania, co nieraz może być fatalne w skutkach.

Okazał Pan tyle zainteresowania się, jeżeli idzie o moje pisanie, że ośmiela mnie to do wypowiedzi na własny temat. To, że nawracam do stron swojej młodości, należy chyba przypisać szczególnej ich właściwości - pobudzającej natchnienie. Wystarczy wyliczyć na chybił trafił dziesięciu autorów polskich, którzy stamtąd to natchnienie brali: Miłosz (Dolina Issy ${ }^{3}$ ), Czernyszewicz (Nadberezyńcy) ${ }^{4}$, Józef Mackiewicz, Sergiusz Piasecki ${ }^{5}$, Putrament (Pięćdziesią lat) ${ }^{6}$, Leopold Buczkowski, Iwaszkiewicz, Wołoszynowski (Opowiadania podolskie ${ }^{7}$ ), Julian Stryjkowski, Vincenz. Od Żmudzi, przez Białoruś, Wołyń, Podole, Ukrainę, po Karpaty to teren najbardziej interesujących książek ostatniego piętnastolecia.

Pisać zacząłem dawno, ale robiłem to dorywczo i błąkając się, pełen skrupułów co do wyboru środków wyrazu i formy. A samo pisanie jest sztuką dosyć przerażająca, kiedy samemu przeczytać, co się napisało. Były przeszkody i innego rodzaju, chociażby to, że jak obliczam sobie to teraz, nosiłem mundur przez prawie siedem lat. Ale późny debiut książkowy ma także swój gorzki urok satysfakcji zapóźnionej młodości.

Myślę, że powinienem oszczędzić Panu dalszych wynurzeń. Chcę tylko zapewnić Pana, że co tylko będę publikował czy pisał dalej, to zawsze w przeświadczeniu, że mogę liczyć na to, że będzie Pan to czytał uważnie i przychylnie.

Proszę pozwolić mi zwrócić się od czasu do czasu listownie do Kochanego Pana, co będzie nie tyle poufałością $z$ mej strony, ile potrzebą i zaufaniem.

Łączę wyrazy szacunku i pozdrowienia

Zygmunt Haupt

List pisany na maszynie, dwa ostatnie zdania odręczne. 
1 Anna Godlewska, matka dr. Juliana Godlewskiego (1903-1983), prawnika, przedsiębiorcy i filantropa (wspierał on m.in. odbudowę Zamku Królewskiego oraz renowację kościoła Wizytek w Warszawie), który postanowił uczcić jej 90 urodziny przyznaniem nagrody dwóm pisarzom emigracyjnym wyłonionym w plebiscycie; nagrodę tę oprócz Stempowskiego otrzymał także Józef Mackiewicz. Zob. Nagroda Literacka Anny Godlewskiej. „Kultura” 1963, nr 9. - Nagroda imienna Anny Godlewskiej. „Wiadomości” 1963, nr 32. - W. A. Z b y s z e w s k i, Dwaj laureaci: Jerzy Stempowski $i$ Józef Mackiewicz. Jw. Zob. też wymianę listów na ten temat między T. Terleckim a J. St em pow skim (Listy 1941-1966. Oprac., przypisy, posł. N. Taylor-Terlecka. Warszawa 2015, s. 134-136). Nagrodę im. Anny Godlewskiej przyznawano jeszcze przez kolejnych 9 lat.

2 Chodzi o Pierścień z papieru Z. Ha u pta (Paryż 1963).

3 Powieść Dolina Issy Cz. Mił o s za miała pierwodruk w Instytucie Literackim w 1955 roku.

4 Czernyszewicz - właśc.: Florian Czarnyszewicz (1895-1964), pisarz ur. w okolicach Bobrujska na Białorusi; jego utwór Nadberezyńcy. Powieść $w$ trzech tomach, osnuta na tle prawdziwych wydarzeń ukazał się po raz pierwszy w Buenos Aires w 1942 roku.

5 Sergiusz Pi a s e k i (1901-1964), powieściopisarz, ur. w Lachowiczach na Białorusi.

6 Haupt ma na myśli wspomnienia J. Pu tra me n ta Pół wieku, których tom 1, Młodość, dotyczący lat 1910-1939, ukazał się nakładem Ministerstwa Obrony Narodowej w Warszawie w 1961 roku.

7 Pierwodruk Opowiadań podolskich J. W oło s zy now s ki e go opublikował Państwowy Instytut Wydawniczy w 1959 roku.

\section{Jerzy Stempowski do Zygmunta Haupta}

Jerzy Stempowski

Nydeggasse 17, Berne

21 VIII [19]63

Kochany Panie,

Najserdeczniej dziękuję za list. To, co Pan pisze o roli kraju pochodzenia w twórczości literackiej, odnosi się także do wielu pisarzy literatury światowej, do czego wrócę niżej. Kraj pochodzenia ma swe miejsce także w tym, co można by nazwać talentem czytelniczym. Pochodzę wprawdzie $z$ innych stron, $z$ dalszej Ukrainy, bliższej Morza Czarnego ${ }^{1}$, ale bywałem w Galicji Wschodniej i uległem też do pewnego stopnia urokowi tego kraju. Okoliczność ta sprawia, że Pańskie opowiadania i Pański list są dla mnie czymś przypominającym rozmowę z przyjacielem.

Świetny krytyk francuski René Dumesnil poświęcił całą obszerną książkę elementom normandzkim u Maupassanta ${ }^{2}$. Zdaniem jego, Maupassant traci połowę talentu, gdy oddala się od tematów normandzkich.

Jeszcze bardziej uderzający jest przykład Sacher-Masocha, który był prawdziwym piewca Galicji Wschodniej. Pisarz ten został całkowicie i niesłusznie zapomniany na skutek spisku niemieckich profesorów, którzy nie mogli mu darować powieści satyrycznej o Berlinie $z$ czasów Bismarcka ${ }^{3}$. Pewnie i Pan go nie zna, powiem więc o nim kilka słów. Sacher-Masoch figuruje dziś tylko w traktatach o patologii seksualnej. To też da się znaleźć w jego ksiażkach i Venus im Pelz ${ }^{4}$ uchodzi słusznie za alfę i omegę masochizmu. Ale, zwłaszcza dla nas, nie to jest w jego dziełach najbardziej interesujące. Sacher-Masoch, ściślej mówiąc: Leopold Ritter von Sacher-Masoch, urodził się w 1835 [roku] we Lwowie jako syn tamtejszego dyrektora policji. Znał na wylot okolice Stanisławowa i Kołomyi i około [roku] 1860 ogłosił swe pierwsze Galizische Erzählungen ${ }^{5}$. Potem był docentem historii 
w Grazu, bardzo wziętym pisarzem, tłumaczonym na obce języki; mieszkał do jakiegoś 1880 [roku] w Wiedniu, po czym przeniósł się do Niemiec Zachodnich i tam umarł w 1895 [roku], zostawiając córkę mieszkającą obecnie w Kolonii ${ }^{6}$. Jakkolwiek nigdy już nie wrócił do Galicji Wschodniej, bredził nią [!] przez całe życie. Pisał dla pieniędzy i zostawił [o]koło 400 tomów bardzo nierównej wartości. Kiedy oddalał się od Galicji Wschodniej, tracił talent. Francuzi wybrali do tłumaczenia opowiadania galicyjskie, których kilkanaście tomów ukazało się w Paryżu w [latach] 1880-1895.

Książki Sacher-Masocha znikły nie tylko z podręczników, nawet najobszerniejszych, literatury niemieckiej, ale także $z$ największych bibliotek w Niemczech. Szukałem ich tam na próżno. We Wiedniu gromadziła je tylko biblioteka Opery, ale i tam brak kilku tomów. W handlu antykwarskim pojawiają się co pewien czas dwa tytuły: Don Juan aus Kolomea, jedyny utwór przedrukowany po śmierci autora przez Ph.[ilippa] Reclama ${ }^{7}$, i Das Vermächtnis Kains, jeden z głównych zbiorów nowel w 3 tomach, wydany rzekomo w Bernie, w istocie w Dreźnie ${ }^{8}$. W tym zbiorze, wybranym przez autora, znajduje się kilka opowiadań galicyjskich i Venus im Pelz oraz dłuższa notatka biograficzna sporządzona przez samego autora i zawierająca większą część tego, co o nim wiadomo. Nieraz przychodziło mi na myśl, że książki Sacher-Masocha łatwiej znaleźć w Ameryce, dokąd nie sięgał spisek profesorów niemieckich.

Rozpisałem się tak o Sacher-Masochu w przypuszczeniu, że ten autor, o ile Pan już go nie zna, może Pana zainteresować. Jest to może najlepszy opis Galicji Wschodniej z połowy ubiegłego stulecia, pełen ciekawych realiów i portretów osobistości ukrytych pod przejrzystymi kryptonimami. Sacher-Masoch musiał być za życia znany w swej ściślejszej ojczyźnie, bo widziałem kiedyś tom jego opowiadań wydanych po polsku w Kołomyi. W 1937 [roku] zainteresowałem nim jednego z wydawców wiedeńskich, który chciał wydać wybór jego opowiadań z moim studium o autorze. Niestety, wypadki przeszkodziły wykonaniu tego projektu.

Najserdeczniejsze wyrazy przyjaźni przesyła Panu szczerze oddany Jerzy Stempowski

List pisany na maszynie, podpis odręczny.

Stempowski wychował się w Szebutyńcach nad Dniestrem na Podolu.

R. D umesnil, Guy de Maupassant. Paris 1947.

Nie udało się ustalić, o jakiej książce pisze Stempowski. Być może, trafny jest domysł Haupta wyrażony w liście 6.

4 Venus im Pelz-powieść L. vo n S a cher-Ma s o cha, opublikowana po raz pierwszy w r. 1870 w czasopiśmie „Die Liebe”; w r. 1920 ukazał się we Lwowie, w Wydawnictwie „Kultura i Sztuka”, polski anonimowy przekład: Wenus $w$ futrze.

5 Galizische Erzählungen - zbiór opowiadań galicyjskich, nie był wydany po polsku.

6 Chodzi o Marthę de Sa cher-Ma s o ch, matkę wspomnianej w liście 7 Mechthild Saternus.

7 Mowa o wydawnictwie Leipzig Philipp Reclam Verlag, które opublikowało wspomnianą książkę w 1926 roku.

8 Zarówno Don Juan aus Kolomea (Donżuan z Kołomyi), jak i Das Vermächtnis Kains (Testament Kaina) nie zostały przetłumaczone na język polski. 


\section{Zygmunt Haupt do Jerzego Stempowskiego}

1021, Oakcrest Road Arlington, Virginia

28/X/[19]63

\section{Szanowny i Kochany Panie!}

Proszę mi wybaczyć, że na list Pański z końca sierpnia odpowiadam z dwumiesięcznym opóźnieniem. Wiem, czym to grozi: po prostu mogę zrazić sobie Pana z wielką szkodą dla siebie i zniechęcić do pisania. Może pewnym wytłumaczeniem się będzie własna obawa zbytniego narzucania się Panu.

O Sacher-Masochu i słyszałem, i czytałem coś dawniej, a nawet pamiętam polski tytuł jego: Wenus $w$ futrze $e^{1}$, ale nie przypominam sobie, bym to czytał. Trochę mnie pewnie zrażał z jego nazwiskiem związany „masochizm” i jakaś galicyjska policyjna parantela, ale teraz, kiedy dowiaduje sie od Pana ciekawych rzeczy, to żałuję, że nie wykorzystałem okazji. Co prawda, żyjąc tutaj: pod Waszyngtonem i niedaleko naprawdę olbrzymiej Biblioteki Kongresu, mógłbym tam poszukać, bo mają tam bardzo wiele rzeczy, a także i dział książek polskich. Tylko że przy niemożliwych w Stanach trudnościach $z$ dojechaniem, a zwłaszcza $z$ parkowaniem samochodu, co zabiera niepomiernie wiele czasu i cierpliwości, a także przy wielkich fatygach i komplikacjach, jakim jest [!] zamawianie i wyczekiwanie w czytelni na zamówiony tom, muszę ze wstydem przyznać się, że do tejże biblioteki rzadko zaglądam. Ale obiecuję sobie poszperać tam za Sacher-Masochem i doniosę Panu, co znalazłem.

Swój brak cierpliwości do systematycznego wyboru i poszukiwania książek wyniosłem $z$ czasów młodości, bo chociaż zawsze wiele czytałem i teraz wiele czytam, to jest to nieporządne i niesystematyczne. Wynikało to $z$ ówczesnych warunków w mych stronach, a i w czasie studiów we Lwowie, kiedy czytało się wszystko, co podpadło pod ręce, bez doboru, rzeczy często przypadkowe, niektóre zadziwiające, których teraz by i nie odnalazł. Na przykład za czasów, kiedy chodziłem do I Gimnazjum we Lwowie, to umieszczono mnie w internacie tamtejszych x.x. zmartwychwstańców i chociaż ówcześni moi wychowawcy księża niewiele zachowali z górnych ideałów Założycieli tej reguły, to mieli w swym zakładzie ogromny i ciekawy księgozbiór. Ich dom lwowski miał jakąś misję objęcia wychowania i nad Ukraińcami i pamiętam także, że mieścił się częściowo w starych zabudowaniach jakiejś dawnej greckokatolickiej instytucji i w dawnej cerkwi pomieścili bibliotekę, do której nikt nie zaglądał i w której bez przeszkód mogłem sobie szperać do woli².

Chcę nawrócić do tematu poruszonego przez Pana: wagi, jaką dla piszącego jest jego kraj własny, zwłaszcza kraj młodości. Zastanawia mnie, jak bardzo jednak mało tego jest u Conrada-Korzeniowskiego, jak niewiele albo wcale nie ma w jego rzeczach śladów życia (pierwszych 17 lat) z Ukrainy czy Krakowa.

To, co mnie zawsze interesowało u Conrada-Korzeniowskiego, to determinacja, z jaką odgrodził się od dawnego życia i w tym nie tylko posłużył się językiem innego narodu, ale i tematem morza i okrętów, $z$ całym tak egzotycznym i odległym z tym związanym opisem życia i po prostu techniki okrętowej, spraw nawigacji, folkloru życia pokładowego, i polscy tłumacze, zwłaszcza Aniela Zagórska ${ }^{3}$, musieli mieć wiele kłopotów $\mathrm{z}$ uporaniem się po prostu z techniczną terminologią morską. 
W rezultacie mamy u Conrada pełno tych bukszprytów, bezanmasztów, foków, logów itp. i już przez sam mechanizm tego dodaje to powieściom jego wiele egzotycznego smaku. A nie doszuka się u niego śladu z zaprzęgów, batów, bryk, którymi przecież za dzieciństwa wozili go i po Ukrainie, i z rodziną na wygnanie, i do Krakowa. Nic z tego nie zostało. (Ubawił mnie u Gombrowicza opis podróży okrętem, gdzie ten sandomierzanin przyrównuje koło sterowe na okręcie do koła u bryczki, a maszty - do dyszli! $\left.{ }^{4}\right)$.

Uderza mnie jeszcze jeden paradoks, kiedy myślę o pisarstwie Conrada. Jego biografowie wspominaja anegdotę o tym młodym Conradzie, który jakoby miał palcem wskazywać sobie białe plamy na ówczesnej mapie Afryki i postanawiać, że kiedyś tam będzie. Dzisiaj na tych samych miejscach ,jądra ciemności” w Afryce sa asfaltowane szosy, kina i stacje benzynowe $\mathrm{TEXACO}^{5}$, a przez paradoks białe plamy dla nas są w miejscach, gdzie Conrad-Korzeniowski się urodził.

Wracając do pisarza, o którym pisze Pan, znów zastanawia mnie osobna literatura „austriacka”, którą zresztą znam słabo. Niedawno wspomnieli w „Wiadomościach" Rotha (Radeckiego marsz) ${ }^{6}$, moim ulubionym autorem jest Hugo von Hofmannstahl ${ }^{7}$, a Haška z jego Szwejkiem ${ }^{8}$ zaliczyłbym jednak do tej „austriackiej” literatury.

Kończąc te słowa, obiecuję na przyszłość odpowiadać wcześniej. Proszę o pamięć i przesyłam słowa pozdrowien

\section{Zygmunt Haupt}

List pisany na maszynie, dwa ostatnie akapity - odręcznie.

Prawdopodobnie chodzi o edycję Wydawnictwa „Kultura i Sztuka” (Lwów 1920).

Zob. na ten temat wspomnienie Z. H a u p a w: Jak się uczyli współcześni pisarze polscy. Odpowiedź na ankiete „,Wiadomości”. „Wiadomości” 1949, nr 19. Przedruk według autografu w: Z Roksolanii. Szkice, opowiadania, recenzje, warianty. Zebrał, oprac., bibliogr., posł. A. Madyda. Toruń 2009.

3 Aniela Za gó r s k a (1881-1943), zachęcona przez samego Conrada, około 1920 r. zajęła się przekładaniem jego twórczości na polski.

$4 \quad$ Nie udało się ustalić, który tekst W. Gombrowicza miał Haupt na myśli.

5 Texaco - amerykański koncern paliwowy.

6 Joseph Roth (1894-1939), ur. w Brodach na Wołyniu powieściopisarz i nowelista austriacki, znany przede wszystkim jako autor powieści Marsz Radetzky'ego (Przeł. W. Kra g e n. Warszawa 1934) i Krypta kapucynów (Przeł. J. Wittli n. Warszawa 1939).

7 Hugo von Hofmannstahl (1874-1929), ur. w Wiedniu austriacki nowelista, dramaturg, eseista i poeta.

$8 \quad$ Przygody dobrego wojaka Szwejka podczas wojny światowej J. H a š k a opublikowało wydawnictwo „Rój” w przekładzie P. Hulki-La skow skiego (Warszawa 1929-1930).

\section{Zygmunt Haupt do Jerzego Stempowskiego}

1021, Oakcrest Road Arlington, Va.

30/XI/[19]63

\section{Szanowny i Kochany Panie!}

Zaintrygowany listem Pana, w którym zalecał Pan Sacher-Masocha, byłem onegdaj w Bibliotece Kongresu i przestudiowałem katalog. Otóż mają tam po niemiecku 
Das Eigentum, Die Republik der Weiberfeinde, Die Messalinen Wiens, Die Liebe ${ }^{1}$, Das Vermächtnis Kains..., w tłumaczeniu na francuski L'Ennemi des femmes, Nouveaux récits galiciens, Les Prussiens d'aujourd'hui (to pewnie to, czym zrobił sobie wrogów w Niemczech), a także po angielsku Venus in Furs ${ }^{3}$ i Jewish Tales ${ }^{4}$. Niektóre $\mathrm{z}$ tych rzeczy miałem nawet $\mathrm{w}$ ręku, a poza tym także $\mathrm{z}$ ciekawości zajrzałem do dwu francuskich dosyć świeżej daty monografii o „chevalier ${ }^{5}$ de Sacher-Masoch”, bo chociaż Ritter von Sacher-Masoch był bardzo świeżej nobilitacji, to Francuzom ten chevalier był potrzebny jako pendant ${ }^{6}$ do markiza de Sade pewnie. $Z$ powierzchownego zapoznania się $z$ tym pisarzem wydaje mi się, że był niezwykły, i wdzięczny jestem Panu za zwrócenie mi na niego uwagi.

Gdybym nie umiał zdobyć się przed Świętami na dłuższy list do Pana, to chcę teraz, tak wcześnie, przesłać Panu życzenia Wesołych Świąt

Zygmunt Haupt

List pisany na maszynie, podpis odręczny.

1 Tytuły te można przetłumaczyć następująco: Das Eigentum - Własność; Die Republik der Weiberfeinde - Republika wrogów kobiet; Die Messalinen Wiens - Messaliny Wiednia; Die Liebe - Miłość.

2 L'Ennemi des femmes - Wróg kobiet; Nouveaux récits galiciens (właśc.: Les Nouveaux récits galiciens) - Nowe opowiadania galicyjskie; Les Prussiens d'aujourd'hui - Prusacy dzisiaj.

3 Venus in Furs - angielska wersja tytułu Wenus $w$ futrze.

4 Jewish Tales - Opowieści żydowskie.

5 le chevalier (fr.) - tytuł szlachecki, odpowiadajacy niemieckiemu tytułowi der Ritter.

6 pendant (fr.) - tu: odpowiednik.

\section{Jerzy Stempowski do Zygmunta Haupta}

Jerzy Stempowski

Nydeggasse 17, Berne

3 XII [19]63

Szanowny i drogi Panie,

Dziękuję serdecznie za list $\mathrm{z}$ wiadomością o Pańskich znaleziskach $\mathrm{w}$ Congress Library. Dodam od razu, że w istocie książek Sacher-Masocha jest tam mniej niż tytułów. Das Vermächtnis Kains jest trzytomowym zbiorem jego dłuższych opowiadań, zawierającym m.in. Venus im Pelz. Das Eigentum i Die Liebe są, jak mi się zdaje, tylko podtytułami z tegoż Vermächtnis, dzielącego się na kilka grup. Ciekawe mogą być Les récits galiciens, bo Francuzi na ogół wybrali do tłumaczenia najlepsze opowiadania. Jewish Tales są zapewne tłumaczeniem obszernego zbioru opowiadań, wchodzącego także częściowo do serii opowiadań galicyjskich. Die Messalinen Wiens i Die Republik der Weiberfeinde są mi nieznane. Być może nie pamiętam ich, bo porzuciłem te książki po kilku stronicach. U Sacher-Masocha najlepsze sąsiaduje dziwnie blisko z najgorszym. Pisał dla pieniędzy i miał niebezpieczną łatwość pisania, prowadząca go przy pisaniu zarobkowym do nieprzyjemnej zamaszystości. Jego ksiażki są jak grzyby: trzeba odróżnić jadalne od trujących.

Nowością dla mnie są francuskie monografie o „chevalier de S.-M.” Wiem tylko, że jego wnuczka, panna Saternus ${ }^{1}$, przygotowywała o nim tezę doktorską. Gdyby Pan miał zanotowane tytuły tych monografii, byłbym Panu bardzo wdzięczny za łaskawą wiadomość o nich, jakkolwiek nie przypuszczam, aby Francuzi mogli coś interesującego na ten temat napisać. 
Według mego zdania dzieła S.-M. zawierają teksty, przy pomocy których można by rozważyć zagadnienie sentymentalizmu. Od 150 lat literatura i sztuka uciekają wciąż na próżno od sentymentalizmu, wpadając tylko w jego nowe odmiany, coraz bardziej nieznośne. I. A. Richards ${ }^{2}$ w Principles of Literary Criticism mówi, że sentymentalizm jest rozbieżnością między wyrazem uczuć i okolicznościami motywującymi te uczucia. Jest więc, powiada, sentymentalizm płaczący bez dostatecznego powodu i sentymentalizm krzepy, nie wiadomo czemu spluwajacy, wzruszajacy ramionami i klnacy siarczystym słowem. Jako przykład tej drugiej odmiany przytacza Hemingwaya. W obawie przed łzami nasi współcześni wpadli w manieryzm krzepy. S.-M. jest typem wybitnie uczuciowym, jak można wnosić chociażby z jego fanatycznego przywiązania do Galicji Wschodniej, ale pisząc, mimo zamaszystości pióra, zatrzymuje się przed nieopatrznym słowem. Te elipsy, litotes ${ }^{3}$, understatements ${ }^{4}$ dają mu najlepsze efekty artystyczne. Zachęcałem pannę Saternus do uwzględnienia tej strony jej dziada, ale nie wiem, czy profesorowie Sorbony, pod których kierunkiem pracowała, aprobowali takie dochodzenia. Jak mogłem wnosić z jej słów, S.-M. był dla nich przede wszystkim rodzajem pendant do markiza de Sade. Dla mnie i zapewne dla Pana będzie przede wszystkim piewcą Galicji Wschodniej, co dla Francuzów jest $d u$ grec $^{5}$ i z czego nawet panna Saternus, wychowana na Węgrzech, nie bardzo sobie zdawała sprawę.

Najserdeczniejsze pozdrowienia przesyła Panu szczerze oddany

J. S.

List pisany na maszynie, inicjały odręczne.

1 Mechthild Saternus (1920-2015), ur. w Berlinie wnuczka po kadzieli autora Wenus $w$ futrze, w latach 1935-1945 przebywała na Węgrzech, uzyskując tam wykształcenie romanistyczne, a po wojnie osiedliła się we Francji, kontynuując pracę naukową; w 1967 r. uzyskała obywatelstwo francuskie.

2 Ivor Armstrong Richards (1893-1979), ur. w Sandbach (Cheshire) w Anglii, jeden z najwybitniejszych XX-wiecznych teoretyków badań literackich; Principles of Literary Criticism (1924) należą do jego najbardziej znanych dzieł.

3 litotes (ang.) - litota, tu: litoty.

4 understatements (ang.) - niedopowiedzenia.

5 du grec (fr.) - przenośnie: niezrozumiałe.

\section{Zygmunt Haupt do Jerzego Stempowskiego}

1021, Oakcrest Road Arlington, Va.

26/I/[19]64

Szanowny i Kochany Panie!

Na list Pański z grudnia ubiegłego roku odpowiadam dopiero teraz, bo chciałem podać Panu bibliografię francuską o Sacher-Masochu, a $z$ tą musiałem poczekać do jednej z mych rzadkich wypraw do Library of Congress. Oto, co tam figuruje:

Amiaux, Mark

...Le chevalier de Sacher-Masoch

Paris, Les Éditions de France, 1938 
Stern, Léopold

...Sacher-Masoch, ou l'amour de la souffrance ${ }^{1}$

Paris, Grasset, 1933.

Chciałbym rozpisać się więcej, zwłaszcza na temat mojej literackiej roboty, ale proszę mnie do tego ośmielić. Będę bardzo zaszczycony i wdzięczny.

Łączę wiele pozdrowień

Zygmunt Haupt

PS. Bardzo ucieszył mnie wybór Parnickiego do zeszłorocznej Nagrody „Kultury”, tym bardziej że to mój stary znajomy ze Lwowa² ${ }^{2}$

List pisany na maszynie, dwa ostatnie zdania odręczne.

$1 \quad$ Sacher-Masoch, ou l'amour de la souffrance (fr.) - w tłumaczeniu: Sacher-Masoch, czyli miłość cierpienia.

2 Teodor Parnicki mieszkał we Lwowie w latach 1928-1940; w 1963 r. otrzymał Nagrodę Literacką „Kultury” za całokształt twórczości. Haupt mógł poznać go albo w r. 1928, przed swoim wyjazdem na studia do Paryża, albo po powrocie - w latach 1933-1939.

\section{Jerzy Stempowski do Zygmunta Haupta}

Jerzy Stempowski

Nydeggasse 17, Berne

11 I [19]66

Szanowny i drogi Panie,

Kiedy nachodzi mnie melancholia lub jakaś nudna choroba, zamykam oczy, wybieram jakiś dobry płaj ${ }^{1}$ i idę nim w myśli powolutku, zatrzymując się na zakosach ścieżki, koło drzew i kęp trawy, które mogę sobie przypomnieće ${ }^{2}$. Ostatnio, z okazji zaburzeń nerwowo-mózgowych, przeszedłem tak granią od Delatyna ${ }^{3}$ przez Rokietę $^{4}$ i Hordie $^{5}$ aż do Kosmackiej Łysiny ${ }^{6}$. Zależnie od ilości znaków zachowanych w pamięci podróż taka trwa dłużej lub krócej, czasami do 6 godzin. Kiedy wreszcie otwieram oczy, czuję się znów żwawy, wolny od ciężaru lat i klęsk. Moje ulubione wędrówki wioda $z$ Burkutu ${ }^{7}$ przez Budyjowska i Czywczyn do Popadii i Albina albo przez Łukawicę i Babę Łudową ${ }^{8}$ do Szykmanów ${ }^{9}$. Znam i inne mało dziś używane szlaki: $z$ Odessy do Chadżybejskiego Limanu ${ }^{10}$ przez słony step z rdzawymi oparzeliskami, obrzeżonymi kryształami soli; ze Żwańca do Chocimia z przeprawą przez Dniestr „Z Laczczyny na Tureczczynu” ${ }^{11}$, jak mówili przewoźnicy, wreszcie z Baru do opisanej w Beniowskim Ladawy ${ }^{12}$. Ta ostatnia podróż wymaga w istocie dwóch dni, ale znaki przydrożne przerzedziły się z czasem w mojej pamięci i starczy ich zaledwie na dwie godziny. Żadne jednak $z$ tych imaginacyjnych wędrówek nie maja równie wybitnej siły leczniczej jak peregrynacje po Karpatach Wschodnich. Ostatni mój kontakt z nimi datuje [się] z końca października 1939. Wyszedłem z karczmy Kamiela w Bohdan-Łuhy ${ }^{13}$ u źródeł Białej Cisy, wspiąłem się na Gutin Tomnatyk $^{14}$, nocowałem w niedźwiedzim barłogu, a potem wzdłuż południowego stoku Czarnohory i Pietrosa ${ }^{15}$ zszedłem na połoninę Szazul ${ }^{16}$ i lasem na Burkut-Kwasy ${ }^{17}$ nad Czarną Cisą. Pamiętam każdy szczegół tej drogi, ale trasa ta nie ma dla mnie leczniczych własności. Szedłem samotnie, głównie nocami przy pełni księżyca, 
walcząc z początkami zapalenia płuc, na które miałem chorować jeszcze przez trzy miesiace w Akna-Szlatina ${ }^{18}$.

Piszę o tym dlatego, że Pan pewnie zna dobrze te podróże. Kto zresztą miałby je znać, jeżeli nie Pan? Różnica między nami polega być może na tym, że jako malarz o wyobraźni bardziej statycznej wywołuje Pan z pamięci oddzielne obrazy, nie zajmując się układaniem ich w serie ciagłe.

Magię tę znał Petrarca. Wszystkie miejsca pobytu opisał jak gdyby w ćwiczeniach topograficznych. Jego łacińskie listy zawierają dziesiątki takich dokładnych opisów. Petrarca uchodzi za pierwszego alpinistę, bo wszedł na Mont Ventoux ${ }^{19}$ - wówczas uchodzący za niedostępny szczyt, jakkolwiek liczy tylko $1900 \mathrm{~m}$ - bez żadnej potrzeby, tylko dla rozrywki.

Literatura jest dziś wybitnie omfaloskopiczna ${ }^{20}$, brak jej wizji świata zewnętrznego. Dostojewski, który tyle jeździł koleją, nie wspomina nigdzie, aby widział coś $\mathrm{z}$ okna wagonu. Szum drzew pod deszczem słyszał u niego tylko Swidrygajłow ${ }^{21}$ nocą przed samobójstwem. Przez pół wieku Dostojewski był ulubioną lekturą elity europejskiej i od niego zaczęła się epoka omfaloskopii w literaturze. Zabieram się właśnie do czytania Mémoire sur les perceptions obscures Maine de Birana ${ }^{22}$, aby zobaczyć, jak wyglądały początki introspekcji, której gust narodził się w czasach Napoleona.

W tej perspektywie Pańskie opowiadania są rewelacją. Przynosza ponowne odkrycie magii Petrarki. Petrarca był bardziej linearny, Pan jest bardziej impresjonistyczny, ale natura obu magii jest pokrewna. Myślałem o Panu w okresie świątecznym i chciałbym, przypominając się Pańskiej łaskawej pamięci, przesłać Panu najserdeczniejsze życzenia, szczerze oddany

\section{Jerzy Stempowski}

List pisany na maszynie, podpis odręczny.

płaj (z ukr.) - szeroka górska ścieżka pasterska.

2 Opisywane w liście okolice Stempowski znał doskonale, ponieważ w latach trzydziestych XX w. spędzał tam co roku kilka miesięcy. Jego związek z tymi stronami był tak ścisły, że na pseudonimy literackie używane w „Kulturze”: Paweł Hostowiec i Leon Furatyk, wybrał sobie nazwy dwóch tamtejszych potoków: Hostowiec i Furatyk - zob. A. S. Kow alc zy k, Nieśpieszny przechodzień i paradoksy. Rzecz o Jerzym Stempowskim. Wrocław 1997, s. 29, 34, przypis 56.

3 Delatyn - miasteczko nad rzeką Prut na południe od Nadwórnej w południowo-Zachodniej Ukrainie. Rokieta - pasmo górskie w Gorganach Zapruckich (ukraińskie Karpaty Wschodnie).

Hordie - szczyt na południe od Rokiety.

Łysina Kosmacka - szczyt między Rokietą a Hordiem.

Burkut - miejscowość w Górach Czywczyńskich (ukraińskie Karpaty Wschodnie), znana dzięki źródłom wody mineralnej.

Budyjowska, Czywczyn, Popadia, Albin, Łukawica, Baba Łudowa - szczyty w Górach Czywczyńskich. Szykmany (obecnie: Probijniwka) - wieś huculska na wschód od Gór Czywczyńskich.

Liman Chadżybejski - słone jezioro w okolicach Odessy.

„z Laczczyny na Tureczczynu” (ukr.) - „z Polski do Turcji”.

Ladawa - niewielki dopływ Dniestru.

Bohdan-Łuhy - wieś na Zakarpaciu.

Gutin Tomnatyk - szczyt w paśmie górskim Czarnohora.

Pietros - szczyt w zachodniej części Czarnohory.

Nie udało się uzyskać żadnych informacji na temat tak nazywającej się połoniny.

Burkut-Kwasy (właśc.: Borkut-Kwasy) - wieś na Zakarpaciu. 
Akna-Szlatina (właśc.: Aknaszlatina, obecnie: Sołotwyno) - miasteczko uzdrowiskowe na Zakarpaciu. Zob. literackie echa choroby w eseju J. Stem powskiego Księgozbiór przemytników („Wiadomości” 1948, nr 20).

19 Mont Ventoux - alpejski szczyt nad deltą Rodanu.

20 omfaloskopiczna (z gr. omphalós 'pępek, środek' + skópeō 'patrzę') - introwersyjna, zamknięta w sobie, koncentrująca się na swoich przeżyciach.

21 Swidrygajłow - postać z powieści Zbrodnia i kara F. D o s toj ew s k i e go.

22 Marie François Pierre Gonthier Maine de Biran (1766-1824), filozof francuski, spirytualista metafizyczny, który głosił, że źródłem wiedzy o świecie zewnętrznym jest pierwotny fakt psychologiczny: wewnętrzne doświadczenie oporu stawianego woli przez jaźń, który to opór dowodzi istnienia rzeczywistości pozapsychicznej; dlatego podmiot zna bezpośrednio tylko siebie, pośrednio zaś - cały świat zewnętrzny, który przedstawia sobie na podobieństwo świata wewnętrznego.

\section{Zygmunt Haupt do Jerzego Stempowskiego}

1057, Waverley Way McLean, Virginia

$$
\text { 23/I/[19]66 }
$$

\section{Szanowny i Kochany Panie!}

Przed paru dniami dostałem list Pański i wybieram się z odpowiedzią, a przede wszystkim z podziękowaniem. Podziwiam Pańska pamięć „topograficzną”, sam przyznam się ze wstydem, że bez mapy nie potrafiłbym tamtejszych szczegółów tak wiernie odtworzyć. Najlepiej znałem Gorgany ${ }^{1}$, mniej Czarnohorę, na narty jeździłem w Bieszczady, gdzie Trościan ${ }^{2}$ koło Sławska będzie dla mnie zawsze najwspanialszą góra narciarską świata. Ale w zacierających się wspomnieniach góry te wydają mi się teraz jak ze snu, jakby mi tylko kiedyś się przyśniły.

Poza listem Pańskim miałem także satysfakcje przeczytania relacji z podróży Pana do Jugosławii, w ostatnim numerze „Kultury”3. Nasunęło mi to bardzo śmiałą i obcesową myśl. Czy Pan, lubiacy podróżować, nie przewiduje w swych planach odwiedzić kiedyś Amerykę? Co prawda pod wieloma względami, tak fizycznymi, jak i w przenośni, jest to pustynia, ale to właśnie może sprzyjać refleksji. Wyobrażam sobie, że nie ominąły Pan wtedy Waszyngtonu i zachciał u nas zatrzymać się (mam dom tuż pod Waszyngtonem, a w stolicy jest największa podobno w świecie Biblioteka Kongresu) ${ }^{4}$.

Łączę wiele serdecznych pozdrowień

\section{Zygmunt Haupt}

List pisany na maszynie, życzenia i podpis odręczne.

1 Gorgany - pasmo górskie na północny zachód od Czarnohory.

2 Trościan - szczyt w Bieszczadach Wschodnich na zachód od Sławska i na dalekie południe od Borysławia i Truskawca; przed wojną mieściło się na nim schronisko turystyczne.

3 P. Hos tow i c [J. S t e m p ow s ki ], Notatnik nieśpiesznego przechodnia. Stońce jesieni. „Kultura” 1966, nr 1/2.

4 Stempowski nigdy nie odwiedził Haupta. 


\title{
Abstract \\ ZYGMUNT HAUPT'S CORRESPONDENCE WITH JERZY STEMPOWSKI
}

Edited by

\author{
ALEKSANDER MADYDA Nicolaus Copernicus University, Toruń \\ ORCID: 0000-0001-6836-9152
}

The correspondence between Zygmunt Haupt and Jerzy Stempowski lasted from April 1963 to January 1966. It was triggered by Haupt's award of "Kultura" ("Culture") Literary Prize for the year 1962 which Haupt owed to Stempowski's positive opinion subsequently published on the pages of the Paris monthly. The substantial differences sketched in the letters between the two figures as far as artistic and stylistic tastes are concerned, as well as marked disproportions in the sphere erudition, education, distinctness of reading interests and Haupt's astonishing admiration for Stempowski's high literary range-all of them explain why the correspondence was short and scarce. All things considered, the correspondence in today reader's eyes become more contribution to Haupt's personality and biography than important source of knowledge about Stempowski. 